\title{
THE OCCURRENCE OF CALCIUM OXALATE IN THE GIDGEE WATTLE (ACACIA CAMBAGEI BAKER).
}

By Thos. Steel.

References in literature to the occurrence of calcium oxalate in plants are numerous, but records of the amounts present are comparatively searce. A few of the more important of the latter may be noted. In 1877, W. M. Hamlet and C. R. Plowright (Chem. News, xxxvi., 1877, p. 93; Journ. Chem. Soc., ii., 1877 , p. 796 ) drew attention to the presence of oxalic acid in a large number of fungi, the acid apparently existing in the free state, as hydric potassium oxalate and as calcium oxalate. Fistularia hepatica ( $86 \%$ water) contained $0.08 \%$ of total oxalic acid, equal to $0.57 \%$ in the dry plant, and equivalent to $0.73 \%$ calcium oxalate $\left(\mathrm{C}_{2} \mathrm{O}_{4} \mathrm{Ca}+\mathrm{H}_{2} \mathrm{O}\right)$.

The presence of the same acid in small amounts in potatoes and malt is recorded by Siewert (Journ. Chem. Soc., 1883, abs, p. 232). Berthelot and Andre (Journ. Chem. Soc., 1886, abs. p. 734) state that they found $13.9 \%$ oxalie acid, which is equivalent to $17.8 \%$ calcium oxalate, in the roots (dry) of Rumex acetosa (common sorrel). Of the $13.9 \%$ oxalie acid, 5.9 was in the soluble state and the remainder insoluble.

H. G. Smith (Journ. Roy. Soe. N.S. Wales, xxxix., 1905, p. 23) in a comprehensive paper describes the occurrence of considerable amounts of ealeium oxalate in the bark of numerous species of Eucalyptus, the percentages present varying from 0.08 to 16.66 of $\mathrm{C}_{2} \mathrm{O}_{4} \mathrm{Ca}+\mathrm{H}_{2} \mathrm{O}$ in the dry bark.

The occurrence of the same substance in cinnamon and cassia barks was recorded by J. Hendrick (Analyst, xxxii., 1907, p. 14) who found from mere traces up to $3.5 \%$ in commercial samples and $6.62 \%$ in one of Ceylon wild cinnamon.

J. Otto (Journ. Soc. Chem. Ind., xxxi, 1912, p. 411) found from 0.4 to $0.9 \%$ calcium oxalate in the young needles of pine trees, while old shoots contained $2.3 \%$ and young lareh leaves $0.1 \%$, all in the dry material.

R. T. Baker (Journ. Roy. Soc. N.S. Wales, li., 1917, p. 435), as the result of microscopic examination, detected crystals of the same compound in the cells of a large number of Australian timbers.

Further references to various phases of this subject will be found in the collective indices of the Chemical Society and of the Society of Chemical Industry.

F. B. Guthrie (Agric. Gazette N.S. Wales, viii., 1897, p. 868) recorded an analysis of the ash of the Gidgee or Stinking Wattle (A. Cambagei), showing $90.7 \%$ of lime $(\mathrm{CaO})$ and $0.40 \%$ potash $\left(\mathrm{K}_{2} \mathrm{O}\right)$. 
Another sample of Gidgee ash offered commercially for manurial purposes and examined by myself in 1898, contained a similar large proportion of lime and small one of potash.

Being struck by the probability of this proportion of lime being due to the presence of unusual amounts of calcium oxalate in the plant, I obtained from Mr. Maiden samples of the timber and bark of A. Cambagei and submitted them to detailed examination, with the results following:-

I have calculated the oxalate as $\mathrm{C}_{2} \mathrm{O}_{4} \mathrm{Ca}+\mathrm{H}_{2} \mathrm{O}$, following $\mathrm{H}$. G. Smith, cited above, who found this to be the constitution of the oxalate separated mechanically from Eucalyptus bark. The method of determination used was similar to that described by Smith, with the exception that I ignited the oxalate precipitate completely and weighed as $\mathrm{CaO}$.

Timber and bark of Acacia Cambagei.

(Calculated to dryness.)

\begin{tabular}{|c|c|c|c|c|c|}
\hline Ash soluble in acid & $\begin{array}{l}\text { Outer } \\
\text { bark: } \\
8.48\end{array}$ & $\begin{array}{c}\text { Inner } \\
\text { bark. } \\
8.43\end{array}$ & $\begin{array}{c}\text { Outer } \\
\text { wood. } \\
\text { (white). } \\
3.28\end{array}$ & $\begin{array}{c}\text { Inner } \\
\text { wood. } \\
\text { (dark). } \\
2.53\end{array}$ & $\begin{array}{r}\text { Average } \\
\text { wood. } \\
2.86\end{array}$ \\
\hline $\begin{array}{llllllll}\text { Sand } & \ldots & \ldots & \ldots & \ldots & \ldots & \ldots & \ldots\end{array}$ & 1.15 & .44 & 0.00 & 0.00 & 0.00 \\
\hline Potash $\left(\mathrm{K}_{2} \mathrm{O}\right) \quad \ldots \quad \ldots r$. & 0.06 & 0.06 & 0.08 & 0.05 & 0.06 \\
\hline Lime as oxalate $\ldots \ldots \ldots$ & 8.20 & 8.16 & 3.08 & 2.46 & 2.70 \\
\hline Total lime $(\mathrm{CaO}) \quad \ldots \quad \ldots c c c$ & 7.22 & 7.22 & 2.23 & 1.46 & 1.8 \\
\hline Calcium oxalate $\left(\mathrm{C}_{2} \mathrm{O}_{4} \mathrm{Ca}+\mathrm{H}_{2} \mathrm{O}\right)$ & 18.82 & 18.82 & 5.81 & 3.81 & 4.77 \\
\hline Water in air-dried & & 9.30 & 9.00 & 9.20 & 9. \\
\hline
\end{tabular}

These proportions of ealcium oxalate in the bark of $A$. Cambagei are the highest I have seen recorded for any plant.

G. Kraus (Journ. Chem. Soc., 1892, abs. p. 1370) concludes from the results of experiments on the bark of various trees which contain calcium oxalate in quantity, that this substance constitutes a reserve deposit and is not an excretion, and that it is redissolved in spring and summer according to the needs of the plant. Branches of Ribes sanguineum and other trees varied in their calcium oxalate content with the seasons, the amount present being highest in winter and lowest in spring and summer. The author states that calcium oxalate is certainly liable to solution by long-continued action of an acid cireulating liquid like cell sap.

The abstract does not give any details regarding the structure or appearance of the bark examined. I feel more than doubtful about this conclusion. A fall in the oxalate content of the bark during the growing period is more likely to be due to the addition of new bark free from oxalate, than to the solution of the oxalate already deposited. Oxalic acid is usually considered a waste product, harmful to the plant, fixed with lime in order to render it insoluble and harmless, and we know that it is shed in large amount in leaves and bark.

We have seen above that the dead, dry, outer bark of A. Cambagei contains the same proportion of oxalate as the inner bark, and even of the latter only a comparatively thin layer may be in metabolic function, in which condition alone it could receive or part with its load of oxalate.

Smith (Journ. Roy. Soe. N.S. Wales, xxix., 1895, p. 325; xxxvii., 1903, p. 107) concluded in the case of Orites excelsa, which he found to contain large amounts of aluminium suceinate, that the suceinic acid was a waste, poisonous 
metabolie product, fixed by the plant with the only available base forming an insoluble succinate, in order to get rid of it.

To determine in how far the barks of other species of Acacia resembled A. Cambagei in ealeium oxalate content, the barks of a number were examined. Through the courtesy of Mr. Maiden I was provided with these from the collections in the Herbarium Museum at the Botanic Gardens, Sydney. The analysis of this series was made for me by my colleague, Mr. E. F. Vaughan, to whom my thanks are due. All the samples were of mature bark which had become thoroughly air dried.

$$
\text { Percentages in Acacia barks (ealeulated to dryness). }
$$

\begin{tabular}{|c|c|c|c|c|c|}
\hline & 1 & 2 & 3 & 4 & 5 \\
\hline Total ash ... . . . & 2.01 & 1.56 & 3.05 & 6.80 & 6.14 \\
\hline Total lime $(\mathrm{CaO}) \quad \ldots \quad \ldots \quad \ldots$ & 1.64 & 0.91 & 2.63 & 2.54 & 4.04 \\
\hline Lime as oxalate $\ldots \begin{array}{lllll} & \ldots & \ldots & \ldots & \ldots\end{array}$ & 0.52 & 0.60 & 1.67 & 2.05 & 2.58 \\
\hline Calcium oxalate $\left(\mathrm{C}_{2} \mathrm{O}_{4} \mathrm{Ca}+\mathrm{H}_{2} \mathrm{O}\right)$ & 1.36 & 1.56 & 4.36 & 5.35 & 6.74 \\
\hline ter in air-drie & & & 13.20 & 9.58 & 12.88 \\
\hline
\end{tabular}

In the total ash the lime was ignited to $\mathrm{CaO}$.

1. A. Choelii Blakely; 2. A. adunca A. Cunn.; 3. A. auriculiformis A. Cunn.; 4. A. decora Reichb.; 5. A. salicina Lindl.; 6. A. aneura F.v.M.

As in the ease of the Eucalyptus barks examined by H. G. Smith there is considerable variation in the amount of oxalate present, but in none of the samples is the high pereentage in A. Cambagei approached. A variable amount of lime is seen to be in combination other than as oxalate. The bark of $A$. decora contained a comparatively large amount of ash insoluble in acid and was high in iron and alumina, which might be due to admixture with earthy matter, but there was nothing in the appearance of the bark to indicate this.

In a lengthy article on the chemistry of forest trees, by $\mathrm{R}$. Warington in Watt's Diet. Chemistry (viii., Ft. 1, 1879, p. 800), a eonsiderable mass of information on the ash constituents of the bark, timber and leaves of trees is collected. A eritical examination of this shows clearly that in most of these lime is the predominating constituent, and that there is never sufficient inorganic acid present to fully satisfy the lime and other bases. Throughout the article no specific mention is made of oxalic acid, though it is stated (p. 809) that the carbon dioxide in the ash represents the organic acids with which the bases were originally united, and that the proportion of bases combined in this way is apparently greater in old than in young wood [and bark.] In the light of present knowledge a study of the data given strongly indicates the presence, in many of these timbers and barks, of very considerable proportions of calcium oxalate. 


\section{$2 \mathrm{BHL}$ Biodiversity Heritage Library}

Steel, T. 1921. "The occurrence of calcium oxalate in the Gidgee wattle (Acacia cambagei Baker)." Proceedings of the Linnean Society of New South Wales 46, 256-258. https://doi.org/10.5962/bhl.part.14015.

View This Item Online: https://www.biodiversitylibrary.org/item/23930

DOI: https://doi.org/10.5962/bhl.part.14015

Permalink: https://www.biodiversitylibrary.org/partpdf/14015

\section{Holding Institution}

MBLWHOI Library

\section{Sponsored by}

MBLWHOI Library

\section{Copyright \& Reuse}

Copyright Status: NOT_IN_COPYRIGHT

This document was created from content at the Biodiversity Heritage Library, the world's largest open access digital library for biodiversity literature and archives. Visit BHL at https://www.biodiversitylibrary.org. 